\title{
Selected arboviral diseases imported to Poland - current state of knowledge and perspectives for research
}

\author{
Anna Kuna ${ }^{1, A-F} \oplus$, Michał Gajewski ${ }^{2, C-F} \oplus$, Beata Biernat ${ }^{3, A, D-F} \oplus$ \\ ${ }^{1}$ Department of Tropical and Parasitic Diseases, Institute of Maritime and Tropical Medicine, Gdynia, Poland; Faculty of \\ Health Sciences, Medical University of Gdańsk, Gdańsk, Poland \\ ${ }^{2}$ Outpatient Clinic of Hepatology, Provincial Hospital, Szczecin, Poland \\ ${ }^{3}$ Department of Tropical Parasitology, Institute of Maritime and Tropical Medicine, Gdynia, Poland; Faculty of Health \\ Sciences, Medical University of Gdańsk, Gdańsk, Poland \\ A - Research concept and design, B - Collection and/or assembly of data, C - Data analysis and interpretation, \\ $D$ - Writing the article, E - Critical revision of the article, F - Final approval of article.
}

Kuna A, Gajewski M, Biernat B. Selected arboviral diseases imported to Poland - current state of knowledge and perspectives for research. Ann Agric Environ Med. 2019; 26(3): 385-391. doi: 10.26444/aaem/102471

\section{Abstract}

Introduction. Arthropod-borne viruses are important causes of human morbidity worldwide. However, the available literatur and the epidemiological data concerning the importation to Poland of globally emerging arboviral infections, such as DENV, CHIKV, WNV, or ZIKV, are scarce. Only few seroepidemiologic studies concerning WNV in animals or humans in Poland have been published.

Objective. The aim of this review paper is to summarize and present the current state of knowledge and the perspectives for research concerning the importation and the risk posed by the introduction to Poland of the four above-mentioned arboviral diseases.

Current state of knowledge. Climate change may facilitate the northward expansion of both the vectors for diseases previously unseen in Europe, as well as of the viruses themselves, resulting in autochthonous cases of diseases previously exclusively imported. Little is known about the importation of arboviral diseases to Poland because of the frequently asymptomatic or self-limiting course of the disease, lack of epidemiologic studies or effective disease reporting, as well as inadequate access to diagnostic methods.

Conclusions. Further epidemiologic studies in Polish travellers are necessary in order to prevent importation or introduction of the above-mentioned viruses, and to act against potential problems related to blood transfusion or organ transplantation from infected donors.

\section{Key words}

arboviruses; Chikungunya; Dengue; West Nile Fever; Zika Virus Infection; communicable diseases, imported

\section{INTRODUCTION}

Arthropod-borne viruses are important causes of human morbidity worldwide. All arboviruses circulate among wild animals, and many cause disease after spillover transmission to humans and agriculturally important livestock that are incidental or dead-end hosts. The arboviruses include a wide variety of the RNA virus, such as Chikungunya (CHIKV), Dengue (DENV), Yellow fever (YFV), Zika (ZIKV), and West Nile fever (WNV), while the only known DNA arbovirus is African swine fever (ASFV) which causes devastating damage in agriculture, but is not known to infect humans [1].

In Poland, Central European tick-borne encephalitis (TBEV) is a well-described human arboviral disease endemic in the country, in particular in the north-eastern regions [2-4]. However, the available literature, as well as the epidemiological data concerning the importation to Poland of globalny-emerging arboviral infections such as DENV, CHIKV, WNV, or ZIKV, are scarce. Only few sero-epidemiologic studies concerning WNV in animals or humans in Poland have been published.

Address for correspondence: Michał Gajewski, Outpatient Clinic of Hepatology Voivodship Hospital, Szczecin

e-mail: mgajewski@gumed.edu.pl

Received: 15.11.2018; accepted: 31.12.2018; first published: 11.02.2019

\section{OBJECTIVE}

The aim of this review paper is to summarize and present the current state of knowledge and the perspectives for research concerning the importation and the risk of introduction to Poland of the four above-mentioned arboviral diseases.

\section{CURRENT STATE OF KNOWLEDGE}

Chikungunya, dengue, West Nile virus and Zika - clinical picture and importance for public health.

1) Chikungunya. Chikungunya fever is a debilitating arthritic disease caused by the chikungunya virus. The virus belongs to the genus Alphavirus of the Togaviridae family and, similar to other arthritogenic alphaviruses, infection with it is commonly characterized by acute fever that progresses to severe, persistent arthralgia in the chronic stage of the disease. The disease is usually selflimiting, but in some patients, debilitating joint pain can persist for years [5]. In the past 15 years, after decades of infrequent, sporadic outbreaks, the virus has caused major epidemic outbreaks in Africa, Asia, the Indian Ocean, and more recently the Caribbean and the Americas. Outbreaks 
of disease caused by an East Central South African (ECSA) genotype have also been reported in Europe. The increased frequency of outbreaks in the past 15 years appears to be associated with a higher incidence of more severe forms of the disease than previously described, with reports of cases of neurological involvement, fulminant hepatitis, and neonatal encephalopathy. The virus usually circulates in a sylvatic cycle between non-human primates or mammalian reservoir hosts and Aedes species mosquitoes. During urban epidemics, chikungunya virus can be transmitted to human hosts through infectious bites by Aedes spp. mosquitoes. Since 2000, the incidence of large outbreaks has increased with the spread of the virus to previously non-endemic regions; moreover, concomitant evidence of genetic adaptation of chikungunya virus to Aedes albopictus has implications for the spread of the virus to non-endemic regions [6]. CHIKV infections have been confirmed in travellers returning to Europe, Australia, the UK, and the USA from endemic regions in the Indian Ocean Islands and Asia. Of particular concern was the local transmission of CHIKV in 2007 in northern Italy, which resulted in 254 locally acquired infections [7]. Ae. albopictus is found in various countries in Europe, while both Ae. albopictus and Ae. aegypti are well-established species in southeastern regions of the USA. Returning travellers with high viraemia could be a source of virus for local Ae. albopictus populations, and there is a risk that CHIKV could establish endemicity in parts of Europe [8].

2) Dengue. Dengue is one of the most important arthropodborne viral diseases. It is endemic in more than 100 countries in tropical and subtropical regions, with around $40 \%$ of the world's population living in areas of increased risk of dengue infection. Every year, 400 million new infections are registered worldwide and about 5\% of them present as the severe form of dengue, with an annual mortality of 25,000. Many reports show a dramatic increase in the geographic range of the disease. Until 1970, it was reported only from 9 countries, but according to the World Health Organization (WHO), as of 2015 the disease is currently present in $\geq 100$ countries of the world, affecting predominantly children, including new cases in Europe (France, Croatia, Madeira in Portugal).

The viral etiological agent of dengue is transmitted primarily by Aedes aegypti and Ae. albopictus mosquitos. The disease is caused by 4 distinct dengue RNA-virus serotypes, i.e. DENV-1, DENV-2, DENV-3, and DENV4 that belong to the Flavivirus genus of the Flaviviridae family. The fifth serotype, DENV-5, which is believed to be limited to the forest canopies of Southeast Asia, has been isolated in 2013; however, the risk of transmission to other regions/countries cannot be ruled out [9].

Clinical presentation can range from mild fever to classical dengue fever with haemorrhage (DHF) and/or shock (dengue shock syndrome [DSS]). Classical dengue fever is an acute infection presenting clinically 4-10 days following the bite of an infected mosquito. The disease is characterized by elevated temperature (up to $40^{\circ} \mathrm{C}$ ), severe headache, retro-orbital pain, malaise, severe joint and muscle pain, nausea, and vomiting, with a rash appearing after 3-4 days after fever onset.

Following a primary infection, the patient is immunologically protected from disease caused by that particular dengue serotype. The severe forms of dengue disease are seen primarily in individuals experiencing a secondary infection with a different dengue serotype. However, primary infection in young infants may also be associated with severe disease outcome. Early in the acute febrile period of the disease, dengue fever presents with the same clinical symptoms as primary dengue. Later, during defervescence, patients can rapidly deteriorate, progressing to haemorrhage with or without vascular leak. During this period, patients can experience bleeding, thrombocytopenia with $<100,000$ platelets $/ \mu \mathrm{L}$, ascites, pleural effusion, increased haematocrit concentrations, severe abdominal pain, restlessness, vomiting, and sudden reduction in temperature with profuse perspiration and adynamia. Currently, there is no antiviral therapeutic option for dengue, with treatment being purely supportive. Nevertheless, the symptoms of DHF and DSS can be effectively managed in most cases by fluid replacement [10]. Clinical sequelae after recovery from an acute dengue virus infection are common in the 2 years following infection. Persistent symptoms are associated with alterations in various immunological parameters and with Fc-gammaRIIa gene polymorphism [11].

3) Zika. Zika virus is a mosquito-borne flavivirus transmitted by Aedes mosquitoes. It is the only human arbovirus known to be transmitted also by the sexual route [12]. In 2007, the first known Zika virus outbreak occurred on the isolated island of Yap, in the western Pacific. Six years later, a larger epidemic occurred in French Polynesia in the south Pacific, followed by smaller outbreaks on other Pacific islands. The virus was introduced into Brazil between 2013-2015, most probably from the Pacific, and caused a large epidemic that peaked in November 2015, subsequently spreading rapidly throughout Brazil and the Americas, while continuing in 2016-2017 to circulate in the Pacific islands. In Brazil, most Zika virus cases have been reported in the northern states and in the southeast region (Rio de Janeiro). As of January 2017, almost all Latin American and Caribbean countries have reported active Zika virus circulation. Although circulation has been documented in Africa over the past 60 years and in Asia over the past 50 years, awareness of Zika virus circulation and the potential for severe disease outcomes increased only after the French Polynesian and Brazilian outbreaks. Enhanced diagnostic techniques and surveillance systems allowed investigation and reporting of autochthonous cases, and new circulation was reported in southeast Asia and Africa.

The clinical presentation of uncomplicated Zika virus infection has been extensively described. Because of its non-specific nature, infection is often not detected or is misdiagnosed. The percentage of asymptomatic infections has been reported to be around $80 \%$; however, a retrospective serosurvey in French Polynesia showed that, among patients who were seropositive for the virus, the percentage of asymptomatic infections was about $30 \%$ in infants and 50\% in adults. In October 2015, a potential link between maternal Zika virus infection and a congenital syndrome was identified in Brazil, when neurologists and physicians in the state of Pernambuco observed an increase in microcephaly cases. In November 2015, the Brazilian Ministry of Health declared a national health emergency. 
In February 2016, this microcephaly epidemic was declared by WHO to be a public health emergency of international concern.

The temporal association between the Zika virus outbreak and severe congenital CNS malformations was also reported in a retrospective analysis conducted in French Polynesia. Compared to uninfected people, the risk ratio of developing brain anomalies was approximately 50 in French Polynesia and Recife, Brazil. Analysis of the Zika virus and microcephaly epidemics in these countries, and in returning travellers in the USA, suggested that the greatest risk of foetal brain anomalies was during the first trimester. Detection of viral RNA in the amniotic fluid, placenta, brain tissue of foetuses and infants with microcephaly, and the high rates of microcephaly among children born to mothers with proved acute Zika virus infection during pregnancy provided strong evidence linking CNS anomalies to maternal infection. By application of Shepard's criteria for the assessment of potential teratogens, it was concluded that a causal relationship existed between prenatal infection with Zika virus and serious brain anomalies [13-16].

4) West Nile virus. West Nile virus (WNV) is a mosquitoborne flavivirus in the Japanese encephalitis antigenic group. WNV has a natural transmission cycle in Culex spp. mosquitoes and wild and captive birds. In contrast, humans and horses are incidental dead-end hosts. The enzootic/epizootic cycle is strictly linked to the period of activity of the arthropod vectors, which, in Europe, results in a season of WNV activity that, depending on the different latitude, ranges from mid-June to mid-November. Since its first recognition in Uganda, the virus has been believed to gradually disperse, via migratory birds, out of Africa to the more southerly regions of Europe, Asia, and Australasia. Up to the mid-1990s, the dispersal of human WNV infections in Europe was mainly in the form of sporadic cases. Outbreaks involving significant numbers of cases presenting with the neuroinvasive disease were first reported in 1994 in Algeria and in 1996 in Romania. WNV was also introduced to the New York area of the USA in 1999, rapidly spreading to four north-eastern states and disseminating outwards in a wave across the entire country over subsequent years. Meanwhile, the virus continued to circulate in Europe and Asia/Australasia. The largest human outbreaks occurred in Bucharest in 1996 (393 hospitalized cases; 17 deaths) and in Russia in 1999 (318 human cases; 40 deaths). Three regions of the Russian Federation-Volgograd, Astrakhan, and Rostov-reported WNV fever/encephalitic activity. Between 1999 and 2010, 928 human cases were identified in the Volgograd area, and 322 and 40 in Astrakhan and Rostov, respectively. Peak epidemic activity was reported in Volgograd in 1999 (380 cases) and 2010 (413 cases). Concerning other countries in the European area, cases of WNV encephalitis were initially recorded in horses in Italy (1998) and southern France (2000). In Italy, the virus reappeared in association with human cases of neurological disease in 2008. In addition, different seropositivity rates have been reported for horses, humans and birds in Spain and Portugal, with the first clinical cases of the WNV-related disease being reported in Spain for horses and humans in 2010. Evidence of WNV circulation among birds has been reported in the UK since 2003, and in 2006, the use of sentinel chickens corroborated the epidemiological data about WNV in the UK by demonstrating actual seroconversion [17].

The year 2018 has seen a resurgence of the virus in Europe: over 1,300 cases of West Nile virus and 90 deaths since the start of the transmission season in June have been recorded. 361 cases have been reported in Italy and 286 in Serbia. Greece (192 cases), Romania (183 cases), and Hungary (155 cases) have also been badly affected. The spike in European cases could be down to the unusually hot summer [18]. Most humans infected with WNV remain asymptomatic. Approximately $20-40 \%$ of infected humans develop symptoms which range from a mild flulike syndrome, West Nile fever (WNF), to severe West Nile encephalitic disease (WNED) [17].

Transmission of arboviral diseases worldwide - trends and control strategies. In order for an arboviral infection to achieve epidemical potential, competent vector and vertebrate host populations must intersect repeatedly within an appropriate environment. Viruses such as DENV and CHIKV that have lost the requirement for enzootic amplification produce now extensive epidemics in tropical urban centres. The global emergence of arboviral diseases is facilitated by the extensive tropical urbanization and colonization of the urban environment by the highly anthropophilic mosquito, Aedes aegypti. These factors led to the establishment of permanent endemic cycles of urban DENV and CHIKV, as well as the seasonal anthroponotic transmission cycle of yellow fever virus (YFV).

The recent invasion into the Americas, Europe and Africa by Aedes albopictus, an important CHIKV and secondary DENV vector, could enhance urban transmission of these viruses in tropical as well as temperate regions [1]. Therefore, diseases such as DENV and CHIKV will continue to emerge until effective vaccines are developed or improved control of urban vector is achieved. Furthermore, increasing international travel and globalization accelerate the introduction of arboviruses into new areas and their geographic expansion.

The ongoing 21st-century emergence of arboviruses highlights the need to reassess research priorities and public health interventions [19]. Various new approaches include infecting Ae. aegypti with the bacteria of the genus Wolbachia, either to decrease their capacity to transmit viruses (YFV, DENV, CHIKV, ZIKV) or to reduce mosquito populations, including sterility in male mosquitos through genetic engineering or irradiation (the wild females with which they mate produce infertile eggs, reducing populations). Advances in genetic engineering technology (e.g. CRISPR-Cas9), which allow highly efficient, targeted transformation and gene-drive systems in mosquitos, are being explored as ways to block transmission or reduce vector populations [20].

Failures of disease control interventions are typically attributed to several factors, including inadequate responses to the virus' strength of transmission, insecticide resistance, expanding Ae. aegypti populations, expansion of urban centres with poor sanitation, human travel networks that disperse the virus and mosquitos, inadequate vector control infrastructure, insufficient resources, inadequate political will, and unsuccessful application of existing strategies. It seems that the combination approach to interventions may 
be the most effective against multiple arboviral diseases and will offer the most cost-effective and sustainable strategy for disease reduction [20].

Competence of arthropods occurring in Poland to transmit human arboviral infections - current perspectives for the introduction of new vector species. Vectorial capacity can be defined as the efficiency of a vector to transmit a pathogen [21]. This depends on many factors, such as the population number, the survivability of the population depending on the environmental conditions, but most of all, on the vector competence which is defined as the ability to contract, maintain and transmit the pathogen.

WNV has been isolated from a dozen of mosquito species which does not necessarily make them competent vectors. Among the mosquito species, Ae. caspius, Ae. detritus, Ae. vexans, Cx. modestus, Cx. torrentium and the biotypes of $C x$. pipiens, as well as their hybrids, have been examined for vector competence. WNV transmission rates have only been determined for four European mosquito species: Ae. albopictus, Ochlerotatus detritus, Cx. modestus and $C x$. pipiens [22]. Of the above-mentioned species, the invasive Ae. albopictus has not been yet detected in Poland, and Oc. detritus and CX. modestus are not abundant. Only $C x$. pipiens is abundant in the whole country, often in plague numbers [23]. It is the predominant vector for WNV in Europe. In the neighboring country of the Czech Republic, three strains of WNV were isolated from Cx. pipiens and Ae. rossicus in 1997, 1999 and 2006. Also in 2013 in Southern Moravia, four strains of lineage $2 \mathrm{WNV}$ were isolated from CX. modestus [24]. The area of Poland is considered by the ECDC as threatened by WNV because of the serologic evidence for WNV circulation in birds [25]; however, WNV epidemics have not been observed in Northern Europe, in spite of the presence of vectors competent for the disease, sometimes in plague numbers, as well as the presence of birds susceptible to infections, and in spite of the geographic proximity of WNV circulation in Southern Europe [26]. On the other hand, several factors influence WNV circulation, with the temperature seeming to be the most important one. Studies that investigated the effect of temperature on the transmission of WNV by European mosquitoes have shown that increasing temperatures result in higher transmission rates [22]. Therefore, the average summer temperature in Poland (observed in the years 1971-2000) ranging depending on the region from $13^{\circ} \mathrm{C}$ to $18^{\circ} \mathrm{C}$ [27] has been a significant factor limiting WNV transmission. It may be for this reason that no confirmed WNV cases in humans have been registered in Poland in spite of the presence of vectors in the country, and the majority of WNV infections in humans have been recorded in Southern Europe, with only a few cases diagnosed in Central Europe [22, 24]. Nevertheless, the occurrence of WNV infections in humans is probable in Poland, especially in the situation of plague occurrence of the vector species during a hot summer.

The vectors for DENV, ZIKV and CHIKV are the invasive species Ae. aegypti and Ae. albopictus. Global spread of these species has historically been related to human trade and transport. Even recently, the introduction of Ae. aegypti through air transport has been documented [28]. Currently, this species is present in Europe on the Black Sea coast [29], but it was historically prevalent in the Mediterranean countries where it was responsible for epidemics of yellow fever, in particular in seaports [25]. Due to the relatively high thermic requirements for development, its establishment in Poland is currently not possible.

Culex species present in Central Europe, including Poland, are known as established vectors, able to transmit numerous viruses including West Nile [30]. Experimental infection and transmission of Zika virus by German populations of $C x$. pipiens (different biotypes) and Cx. torrentium showed that they do not have vector competence for ZIKV; however, Ae. albopictus (German population) were susceptible for ZIKV but only at $27^{\circ} \mathrm{C}$ [30]. Ae. albopictus has already been detected in the countries neighboring Poland: the Czech Republic [31], Slovakia [32], and Germany, where its occurrence is already massive [33]. Thus, it is only a matter of time before it occurs in Poland, or it may even be already present, but as yet undetected.

\section{CHIKV, DENV, WNV and ZIKV importation and risk of introduction to Poland.}

a) Chikungunya. As of June 2018, no clinical cases or seroepidemiologic studies concerning the infection have been described in Poland [34].

b) Dengue. According to the European Centre for Disease Prevention and Control, 1,796 dengue cases were recorded in the years 2010-2014 in Europe, of which 1,510 were laboratory confirmed. About $78.8 \%$ of the cases were imported from Asia and 10\% from South America. Seasonality was observed with increase in number of infections between June and October [9]. Autochthonous cases reported in southern Europe (France, Croatia, Madeira in Portugal) show that this disease re-emerged in Europe and, with the increasing interest in foreign travels to tropical countries regarded as dengue endemic areas, the number of imported dengue cases in Poland may rise in the future [9]. Since 2005 in Poland, laboratory diagnosis of dengue has been available in selected centres for tropical medicine [35]. There is no specific obligation to report dengue to the health authorities; instead, there is only a general requirement to report 'viral haemorrhagic fevers, including yellow fever' [36]. Consequently, the official data on the number of Poles suffering from dengue are not reliable. Nevertheless, the median number of cases recorded annually in Poland in 2009-2013 was five cases [37], while 2016 and 2017 saw a sharp increase in the number of officially registered cases per year (41 cases and 28 cases, respectively) [38]. A previous seroepidemiologic study conducted at our centre in Gdynia returned inconclusive results [39]. Patients returning from the tropics are usually diagnosed in one of the centers of tropical medicine, including our reference center situated in Gdynia. The majority of patients diagnosed and treated In his centre had returned from Asia; however, attention has also been drawn to a large group of patients returning from Africa, reflecting the geographic expansion of dengue viruses [9]. The 22 patients treated at the Warsaw centre travelled mainly to South-East Asia (Thailand, Laos, Vietnam), followed by India and Mexico [40]. In 2006-2009, a total 69 blood sera of patients returning from endemic regions of the diseases and treated at the Gdynia centre were tested for DENV RNA. It was detected in the blood of 10 patients. Six sequences, derived from patients returning from South 
America (Brazil), Africa (Chad) and Asia (Thailand, Indonesia), were identical with DENV-1 serotype. Two sequences from Asia (Thailand and India) were identical with DENV-2 serotype and another two (Philippines and Thailand) with DENV-3 [41].

In spite of the severe course of the disease observed in some cases $[9,42]$, dengue is often a self-limiting febrile illness, self-treated by the patients without seeking any medical help or seeking it only at an outpatient clinics, and therefore, the overall real number of dengue cases imported to Poland is probably higher [9], in parallel with the findings of a previous study concerning the real incidence of malaria importation [43].

c) Zika. To date, not a single case of ZIKV has been officially registered or published in Poland [44], although the reports available in the common press suggest (albeit without providing any details) that sera from two patients were identified in mid-2016 as positive for ZIKV at an experimental laboratory running as a spin-off company of the University of Warsaw [45], as well as one sample from a third patient at the National Institute for Public Health / National Institute for Hygiene [46].

d) West Nile virus. The official position of the Polish health authorities has remained that WNV is not present in the country [47]. The review by Moniuszko-Malinowska et al. summarized the state of knowledge regarding the presence of WNV in Poland, as of 2016 [48]. The risk of WNV presence in Poland was mentioned for the first time in 1995-1996, when anti-WNV antibodies were detected in $2.8 \%$ of examined house sparrows and $12.1 \%$ Eurasian tree sparrows in Łomianki (near Kampinos Forest located on the northwestern outskirts of Warsaw) [49]. A case of human WNV infection confirmed with serologic methods was described in a patient hospitalized because of fever, headache, muscle pain and diarrhea [50]; moreover, foresters from two regions (Świętokrzyskie and Podlaskie) were tested in 2006 for the presence of antiWNV IgG antibodies in serum with a positive result in one of 52 (1.9\%) examined foresters in Świętokrzyskie and four of 42 in Podlaskie [51]. On the other hand, a study conducted in 2007-2010 examined brain tissue samples of migratory birds by RT-PCR and serologic methods, but did not find proof of WNV infection $[52,53]$, while neither an assay performed in 24 patients hospitalized because of meningitis [54] nor a study in 80 patients with encephalitis [55] found WNV RNA in any of the analyzed cerebrospinal fluid samples. An earlier study of 15,400 mosquito females collected in 2004-2009 at indoor and outdoor collection sites in the Polish districts of KujawskoPomorskie, Mazowieckie, Podlaskie and WarmińskoMazurskie (where the predominant species was Culex pipiens, accounting for over $42 \%$ of total insects collection) found no WNV RNA in the examined specimens [56]. In a 2008 study, specific antibodies were detected with plaque-reduction neutralization microtesting (PRNT) in five juvenile (hatching-year) birds collected in 2006: three white storks (Ciconia ciconia) in a wildlife rehabilitation centre $(5.4 \%$ of all examined storks; the antibody titers in each bird were 1:320,1:160, and 1:20), one free-living mute swan (Cygnus olor; the titer was 1:20), and one hooded crow (Corvus corone cornix; titer 1:20) in a wildlife rehabilitation centre; Thus, the overall seropositivity to WNV was $5.2 \%$ among all the birds sampled [57].

In another study published in 2015, analysis of serum samples from birds (white storks, common pheasants, common chaffinches, wild ducks, white-tailed eagles, passenger pigeons, goshawks, hooded crows, northern goshawks, common swift, common blackbird, common starling, common raven, and common buzzard), confirmed the presence of anti-WNV antibodies in 63/474 (13.29\%) of the examined wild birds, in 1/378 (0.26\%) horse and 14/42 (33.33\%) humans. All positive samples from birds were confirmed with PRNT method [58]. In a study published in 2018, virus neutralizing antibodies against WNV were detected in five of the 14 birds tested (35.7\%) and in 62 horses of 411 tested (15.08\%). Seropositive horses were found in different provinces in Poland. Twenty-one of serologically positive horses (33.87\%) did not travel outside Polish borders. The remaining horses travelled to Germany (23 horses), Hungary (9 horses), the Netherlands (4 horses), Lithuania (2 horse), Austria (1 horse), France (1 horse), and Slovakia (1 horse) [59]. Positive results of samples from birds, horses and humans may indicate that WNV is connected with the Polish ecosystem [48].

The presence of WNV observed in many European countries, including the countries neighbouring Poland (Czech Republic, Ukraine) and the occurrence of Cx. pipiens s.l. and Cx. torrentium in Polish cities (Gdańsk, Warsaw, Wrocław, Swinoujście and Szczecin) support the hypothesis of the high probability of the occurrence of WNV in Poland $[60,61]$. Cx. pipiens is abundant in Poland [23], including in the cities, and its share in the total population of mosquitoes may rise in various parts of the country after events such as floods. In the city of Gdańsk, its share before the 2001 flood was approximately $24 \%$, while directly after the flooding it was $97 \%$ and after one year it still persisted at 76\% [62].

For these reasons, WNV should be included in differential diagnostic of meningitis but the risk of crossreactivity must be taken into account (see below).

Cross-reactivity of antibodies against flaviviruses implications for sero-epidemiologic studies in Poland. The diagnosis of flavivirus infection may be complicated because of cross-reactivity with envelope proteins of related flaviviruses or nonspecific reactivity [63]. Cross-reactive results in sera occur more frequently among patients with previous flavivirus infection or vaccination against a related flavivirus. This cross-reactivity is particularly extensive between ZIKV and DENV [63]. As a result of these crossreactivity and nonspecific reactivity issues, testing algorithms have generally recommended that all positive and equivocal virus-specific IgM results should be confirmed with the more specific plaque reduction neutralization test (PRNT) [63].

The PRNT can measure virus-specific neutralizing antibody titers against ZIKV, DENV, and other flaviviruses to which the person might have been exposed [64]. In some situations, the PRNT can resolve nonspecific reactivity and discriminate between cross-reacting antibodies because neutralizing antibodies bind with virus-specific antigens and, unlike ELISA, the PRNT is a quantitative assay in which titers are compared. However, in persons previously infected with or vaccinated against a flavivirus such as TBEV or YFV, discriminating between cross-reactive antibodies might still 
be difficult. A person previously infected with a flavivirus, when exposed to another flavivirus, can have a rapid rise in neutralizing antibodies against multiple flaviviruses because their immune system recognizes and reacts to shared epitopes among these viruses [63]. It may be impossible to determine which flavivirus is causing the patient's illness, resulting in the diagnosis of an unspecified flavivirus infection [63].

\section{CONCLUSIONS}

A significant expansion is currently being experienced in the geographic range of dengue and possibly other arboviral diseases. The climate change may facilitate the northward expansion of both the vectors for diseases previously unseen in Europe, as well as of the viruses themselves, resulting in autochthonous cases of diseases previously exclusively imported. Little is known about the importation of arboviral diseases to Poland because of the frequently asymptomatic or self-limiting course of the disease, lack of epidemiologic studies or effective disease reporting, as well as inadequate access to diagnostic methods. Further epidemiologic studies in Polish travellers are necessary in order to prevent possible importation of the viruses, and to act against potential problems related to blood transfusion or organ transplantation from infected donors.

\section{Conflict of interests}

None declared.

\section{Aknowledgement}

The authors gratefully acknowledge the funding of his study by statutory Research Grant No. 02-0136/07 from the Medical University of Gdańsk, Poland.

\section{REFERENCES}

1. Weaver SC, Reisen WK. Present and future arboviral threats. Antiviral Res. 2010; 85(2): 328-45. Epub 2009/10/24. doi: 10.1016/j. antiviral.2009.10.008. PubMed PMID: 19857523; PubMed Central PMCID: PMCPMC2815176.

2. Paradowska-Stankiewicz I, Piotrowska A. Meningitis and encephalitis in Poland in 2015. Przegl Epidemiol. 2017; 71(4): 493-500. PubMed PMID: 29415527.

3. Stefanoff P, Rubikowska B, Bratkowski J, Ustrnul Z, Vanwambeke SO, Rosinska M. A Predictive Model Has Identified Tick-Borne Encephalitis High-Risk Areas in Regions Where No Cases Were Reported Previously, Poland, 1999-2012. Int J Environ Res Public Health. 2018; 15(4). Epub 2018/04/04. doi: 10.3390/ijerph15040677. PubMed PMID: 29617333 ; PubMed Central PMCID: PMCPMC5923719.

4. Czupryna P, Grygorczuk S, Krawczuk K, Pancewicz S, Zajkowska J, Dunaj J, et al. Sequelae of tick-borne encephalitis in retrospective analysis of 1072 patients. Epidemiol Infect. 2018; 146(13): 1663-70. Epub 2018/07/26. doi: 10.1017/S0950268818002005. PubMed PMID: 30047354.

5. Burt F, Chen W, Mahalingam S. Chikungunya virus and arthritic disease. Lancet Infect Dis. 2014; 14(9): 789-90. doi: 10.1016/S14733099(14)70869-2. PubMed PMID: 25164188.

6. Burt FJ, Chen W, Miner JJ, Lenschow DJ, Merits A, Schnettler E, et al. Chikungunya virus: an update on the biology and pathogenesis of this emerging pathogen. Lancet Infect Dis. 2017; 17(4): e107-e17. Epub 2017/02/01. doi: 10.1016/S1473-3099(16)30385-1. PubMed PMID: 28159534.

7. Rezza G, Nicoletti L, Angelini R, Romi R, Finarelli AC, Panning $\mathrm{M}$, et al. Infection with chikungunya virus in Italy: an outbreak in a temperate region. Lancet. 2007; 370(9602): 1840-6. doi: 10.1016/ S0140-6736(07)61779-6. PubMed PMID: 18061059.
8. Burt FJ, Rolph MS, Rulli NE, Mahalingam S, Heise MT. Chikungunya: a re-emerging virus. Lancet. 2012; 379(9816): 662-71. Epub 2011/11/17. doi: 10.1016/S0140-6736(11)60281-X. PubMed PMID: 22100854.

9. Kuna A, Bykowska M, Kulawiak N, Biernat B, Szostakowska B, Nahorski WL, et al. Clinico-laboratory profile of dengue patients returning from tropical areas to Poland during 2010-15. J Vector Borne Dis. 2016; 53(3): 234-9. PubMed PMID: 27681546.

10. Muller DA, Depelsenaire AC, Young PR. Clinical and Laboratory Diagnosis of Dengue Virus Infection. J Infect Dis. 2017; 215(suppl_2): S89-S95. doi: 10.1093/infdis/jiw649. PubMed PMID: 28403441.

11. García G, González N, Pérez AB, Sierra B, Aguirre E, Rizo D, et al. Long-term persistence of clinical symptoms in dengue-infected persons and its association with immunological disorders. Int J Infect Dis. 2011; 15(1): e38-43. Epub 2010/11/26. doi: 10.1016/j.ijid.2010.09.008. PubMed PMID: 21112804.

12. Kuna A, Gajewski M. Prevention of sexual transmission of Zika virus. Int Marit Health. 2016; 67(3): 179-80. doi: 10.5603/IMH.2016.0033. PubMed PMID: 27681219.

13. Baud D, Gubler DJ, Schaub B, Lanteri MC, Musso D. An update on Zika virus infection. Lancet. 2017; 390(10107): 2099-109. Epub 2017/06/21. doi: 10.1016/S0140-6736(17)31450-2. PubMed PMID: 28647173.

14. Korzeniewski K, Juszczak D, Zwolińska E. Zika - another threat on the epidemiological map of the world. Int Marit Health. 2016; 67(1): 31-7. doi: 10.5603/IMH.2016.0007. PubMed PMID: 27029927.

15. Płusa T. [Zika virus as a new threat to the health and life]. Pol Merkur Lekarski. 2016; 40(237): 149-52. PubMed PMID: 27088194.

16. Kwaśniewski W, Stachowicz N, Stupak A, Kwaśniewska A, GoździckaJozefiak A. [What do we konw about the Zika virus?]. Wiad Lek. 2016; 69(3 pt 2): 560-4. PubMed PMID: 27717945.

17. Sambri V, Capobianchi M, Charrel R, Fyodorova M, Gaibani P, Gould E, et al. West Nile virus in Europe: emergence, epidemiology, diagnosis, treatment, and prevention. Clin Microbiol Infect. 2013; 19(8): 699704. Epub 2013/04/17. doi: 10.1111/1469-0691.12211. PubMed PMID: 23594175.

18. Burki T. Increase of West Nile virus cases in Europe for 2018. Lancet. 2018; 392(10152): 1000. Epub 2018/09/20. doi: 10.1016/S01406736(18)32286-4. PubMed PMID: 30264694

19. Wilder-Smith A, Gubler DJ. Geographic expansion of dengue: the impact of international travel. Med Clin North Am. 2008; 92(6): 1377-90, x. doi: 10.1016/j.mcna.2008.07.002. PubMed PMID: 19061757.

20. Wilder-Smith A, Gubler DJ, Weaver SC, Monath TP, Heymann DL, Scott TW. Epidemic arboviral diseases: priorities for research and public health. Lancet Infect Dis. 2017; 17(3): e101-e6. Epub 2016/12/21. doi: 10.1016/S1473-3099(16)30518-7. PubMed PMID: 28011234.

21. GARRETT-JONES C. PROGNOSIS FOR INTERRUPTION OF MALARIA TRANSMISSION THROUGH ASSESSMENT OF THE MOSQUITO'S VECTORIAL CAPACITY. Nature. 1964; 204: 1173-5. PubMed PMID: 14268587.

22. Vogels CB, Göertz GP, Pijlman GP, Koenraadt CJ. Vector competence of European mosquitoes for West Nile virus. Emerg Microbes Infect. 2017; 6(11): e96. Epub 2017/11/08. doi: 10.1038/emi.2017.82. PubMed PMID: 29116220; PubMed Central PMCID: PMCPMC5717085.

23. Kubica-Biernat B. Distribution of mosquitoes (Diptera: Culicidae) in Poland. Eur Mosq Bull. 1999; 5: 1-17.

24. Rudolf I, Bakonyi T, Sebesta O, Mendel J, Peško J, Betášová L, et al. West Nile virus lineage 2 isolated from Culex modestus mosquitoes in the Czech Republic, 2013: expansion of the European WNV endemic area to the North? Euro Surveill. 2014; 19(31): 2-5. Epub 2014/08/07. PubMed PMID: 25138970.

25. ECDC. West Nile virus risk assessment tool. Stockholm: European Centre for Disease Prevention and Control, 2013.

26. Vogels CB, Fros JJ, Göertz GP, Pijlman GP, Koenraadt CJ. Vector competence of northern European Culex pipiens biotypes and hybrids for West Nile virus is differentially affected by temperature. Parasit Vectors. 2016; 9(1): 393. Epub 2016/07/07. doi: 10.1186/s13071016-1677-0. PubMed PMID: 27388451; PubMed Central PMCID: PMCPMC4937539.

27. Climate in Poland: Institute of Meteorology and Water Economy; [cited 2018 June 1]. Available from: http://old.imgw.pl/klimat/\#.

28. Ibañez-Justicia A, Gloria-Soria A, den Hartog W, Dik M, Jacobs F, Stroo A. The first detected airline introductions of yellow fever mosquitoes (Aedes aegypti) to Europe, at Schiphol International airport, the Netherlands. Parasit Vectors. 2017; 10(1): 603. Epub 2017/12/08. doi: 10.1186/s13071-017-2555-0. PubMed PMID: 29221490; PubMed Central PMCID: PMCPMC5723084.

29. ECDC. Aedes aegypti - current known distribution in Europe, April 2017 Stockholm: European Centre for Disease Prevention and Control; 
2017 [cited 2018 Jun 1]. Available from: https://ecdc.europa.eu/en/ publications-data/aedes-aegypti-current-known-distribution-europeapril-2017.

30. Heitmann A, Jansen S, Lühken R, Leggewie M, Badusche M, Pluskota $B$, et al. Experimental transmission of Zika virus by mosquitoes from central Europe. Euro Surveill. 2017; 22(2). doi: 10.2807/1560-7917. ES.2017.22.2.30437. PubMed PMID: 28106528; PubMed Central PMCID: PMCPMC5404485.

31. Šebesta O, Rudolf I, Betášová L, Peško J, Hubálek Z. An invasive mosquito species Aedes albopictus found in the Czech Republic, 2012. Eurosurveillance. 2012; 17(43): 20301. doi: 10.2807/ese.17.43.20301-en.

32. Bocková E, Kočišová A, Letková V. First record of Aedes albopictus in Slovakia. Acta Parasitol. 2013; 58(4): 603-6. Epub 2013/12/13. doi: 10.2478/s11686-013-0158-2. PubMed PMID: 24338326.

33. Becker N, Schön S, Klein AM, Ferstl I, Kizgin A, Tannich E, et al. First mass development of Aedes albopictus (Diptera: Culicidae)-its surveillance and control in Germany. Parasitol Res. 2017; 116(3): 847-58. Epub 2017/01/23. doi: 10.1007/s00436-016-5356-z. PubMed PMID: 28116530; PubMed Central PMCID: PMCPMC5313584.

34. Knap JP, Swiatecka A, Kucharska I, Debiński W, Czyrznikowska A. [Management in Chikungunya virus infection--a new threat for Europe]. Pol Merkur Lekarski. 2010; 28(166): 331-5. PubMed PMID: 20491349.

35. Pancer K, Szkoda MT, Gut W. Imported cases of dengue in Poland and their diagnosis. Przegl Epidemiol. 2014; 68(4): 651-5. PubMed PMID: 25848785 .

36. Act of December 5, 2008 on preventing and combatting infections and infectious diseases in humans, Appendix 1 (official consolidated text), (2018).

37. Sadkowska-Todys M, Zieliński A, Czarkowski MPMP. Infectious diseases in Poland in 2015. Przegl Epidemiol. 2017; 71(3): 295-309. PubMed PMID: 29181956.

38. Sadkowska-Todys M, Zieliński A, Czarkowski MP. Infectious diseases in Poland in 2016. Przegl Epidemiol. 2018; 72(2): 129-41. PubMed PMID: 30111085.

39. Goljan J, Myjak P, Nahorski W, Kubica-Biernat B, Felczak-Korzybska I, Kowalczyk D, et al. Dengue antibodies in Polish travellers returning from the tropics. Evaluation of serological tests. Int Marit Health. 2010; 61(1): 36-40. PubMed PMID: 20496327.

40. Olszyńska-Krowicka M, Switaj K. [Dengue in patients hospitalized in the hospital ward of zoonoses and tropical diseases in Warsaw in years 2002-2011]. Przegl Epidemiol. 2011; 65(4): 571-5. PubMed PMID: 22390041

41. Biernat B, Stańczak J, Szostakowska B, Wroczyńska A, Kuna A Nahorski WL, et al. Different serotypes of dengue virus (DENV) imported by Polish travellers from dengue endemic areas to Poland. Int Marit Health. 2015; 66(2): 72-6. doi: 10.5603/IMH.2015.0018. PubMed PMID: 26119675.

42. Kuna A, Wroczyńska A, Gajewski M, Felczak-Korzybska I, Nahorski WL. A case of acalculous cholecystitis in the course of dengue fever in a traveller returned from Brazil. Int Marit Health. 2016; 67(1): 38-41. doi: 10.5603/IMH.2016.0008. PubMed PMID: 27029928.

43. Kuna A, Szostakowska B, Nahorski WL, Stępień M, Kowalczyk D, Stańczak J, et al. An attempt to estimate the minimal number of Poles infected and treated for malaria in Poland and abroad. Int Marit Health. 2015; 66(4): 233-7. doi: 10.5603/IMH.2015.0044. PubMed PMID: 26726894

44. Gańczak M. Zika--an emerging infectious disease. The risk assessment from Polish perspective. Przegl Epidemiol. 2016; 70(1): 1-6, 93-7. PubMed PMID: 27344465.

45. [First two confirmed cases od Zika virus infection in Poland] [Internet]. Polska Agencja Prasowa; 2016 [cited 30 Jun 2018]. Available from: http:// www.pap.pl/aktualnosci/news,616671,pierwsze-dwa-potwierdzonezakazenia-wirusem-zika-w-polsce.html

46. [NIZP-PZH confirmed Zika infection in one Polish woman] [Internet]. Polska Agencja Prasowa; 2016 [cited 30 Jun 2018]. Available from: http:// www.pap.pl/aktualnosci/kraj/news,618768,nizp-pzh-potwierdzilzakazenie-wirusem-zika-u-jednej-polki.html

47. Knap JP, Kubica-Biernat B. [Did West Nile Fever (WNF) appear in Poland? Position of the Expect Committee appointed by the Chief Sanitary Inspector]. Przegl Epidemiol. 2003; 57(3): 399-404. PubMed PMID: 14682157.

48. Moniuszko-Malinowska A, Czupryna P, Dunaj J, Zajkowska J, Siemieniako A, Pancewicz S. West Nile virus and USUTU--a threat to Poland. Przegl Epidemiol. 2016; 70(1): 7-10, 99-102. PubMed PMID: 27344466.
49. Juricová Z, Pinowski J, Literák I, Hahm KH, Romanowski J. Antibodies to alphavirus, flavivirus, and bunyavirus arboviruses in house sparrows (Passer domesticus) and tree sparrows (P. montanus) in Poland. Avian Dis. 1998; 42(1): 182-5. PubMed PMID: 9533098.

50. Hermanowska-Szpakowicz T, Grygorczuk S, Kondrusik M, Zajkowska J, Pancewicz S. [Infections caused by West Nile virus]. Przegl Epidemiol. 2006; 60(1): 93-8. PubMed PMID: 16758745.

51. Kondrusik M, Ferenczi E, Zajkowska J, Pancewicz S, Grygorczuk S, Swierzbińska R, et al. [The evaluation of serum presence of antibodies reacting with West Nile Fever virus (WNV) antigens among inhabitants from Podlaskie and Swietokrzyskie region]. Przegl Epidemiol. 2007; 61(2): 409-16. PubMed PMID: 17956061.

52. Niczyporuk JS, Samorek-Salamonowicz E, Kozdruń W, Mizak Z. Attempts to detect West Nile virus in wild birds in Poland. Acta Vet Hung. 2011; 59(3): 405-8. doi: 10.1556/AVet.2011.023. PubMed PMID: 21727072 .

53. Niczyporuk JS, Samorek-Salamonowicz E, Mizak WK. The survey of wild birds for West Nile virus in Poland. Pol J Vet Sci. 2011; 14(4): 573-7. PubMed PMID: 22439327.

54. Czupryna P, Niczyporuk J, Samorek-Salamonowicz E, Moniuszko A, Dunaj J, Zajkowska J, et al. Detection of West Nile Virus RNA in patients with meningitis in Podlaskie Province. Przegl Epidemiol. 2014; 68(1): 17-20, 109-11. PubMed PMID: 25004626.

55. Jabłońska J, Popiel M, Bukowska-Ośko I, Perlejewski K, Cortés KC, Horban A, et al. No evidence of West Nile virus infection among Polish patients with encephalitis. Cent Eur J Immunol. 2016; 41(4): 383-5. Epub 2017/01/24. doi: 10.5114/ceji.2016.65137. PubMed PMID: 28450801; PubMed Central PMCID: PMCPMC5382883.

56. Kubica-Biernat B, Kruminis-Łozowska W, Stańczak J, Cieniuch S. [A study on the occurrence of West Nile virus in mosquitoes (Diptera: Culicidae) on the selected areas in Poland]. Wiad Parazytol. 2009; 55(3): 259-63. PubMed PMID: 19856843.

57. Hubálek Z, Wegner E, Halouzka J, Tryjanowski P, Jerzak L, Sikutová $\mathrm{S}$, et al. Serologic survey of potential vertebrate hosts for West Nile virus in Poland. Viral Immunol. 2008; 21(2): 247-53. doi: 10.1089/ vim.2007.0111. PubMed PMID: 18433332.

58. Niczyporuk JS, Samorek-Salamonowicz E, Lecollinet S, Pancewicz SA, Kozdruń W, Czekaj H. Occurrence of West Nile virus antibodies in wild birds, horses, and humans in Poland. Biomed Res Int. 2015; 2015 : 234181. Epub 2015/03/19. doi: 10.1155/2015/234181. PubMed PMID: 25866767; PubMed Central PMCID: PMCPMC4383358.

59. Bażanów B, Jansen van Vuren P, Szymański P, Stygar D, Frącka A, Twardoń J, et al. A Survey on West Nile and Usutu Viruses in Horses and Birds in Poland. Viruses. 2018; 10(2). Epub 2018/02/17. doi: 10.3390/ v10020087. PubMed PMID: 29462983.

60. Weitzel T, Jawień P, Rydzanicz K, Lonc E, Becker N. Culex pipiens s.l. and Culex torrentium (Culicidae) in Wrocław area (Poland): occurrence and breeding site preferences of mosquito vectors. Parasitol Res. 2015; 114(1): 289-95. Epub 2014/10/24. doi: 10.1007/s00436-014-4193-1. PubMed PMID: 25339516.

61. Wegner E. Mosquito fauna (Diptera: Culicidae) of five different towns in Poland with special reference to the occurrence of human disease vectors. Fragmenta Faunistica. 2008; 51(1): 15-22. doi: 10.3161/00159 301FF2008.51.1.015.

62. Kubica-Biernat B, Kowalska-Ulczyńska B, Stańczak J, [Mosquitoes (Diptera: Culicidae) of the Tricity]. In: Buczek A, Błaszak C, editors. [Arthropods: Environment, pathogens and hosts]. Lublin: Koliber; 2007. p. 61-6.

63. Lindsey NP, Staples JE, Powell K, Rabe IB, Fischer M, Powers AM, et al. Ability To Serologically Confirm Recent Zika Virus Infection in Areas with Varying Past Incidence of Dengue Virus Infection in the United States and U.S. Territories in 2016. J Clin Microbiol. 2018; 56(1). Epub 2017/12/26. doi: 10.1128/JCM.01115-17. PubMed PMID: 29093104; PubMed Central PMCID: PMCPMC5744200.

64. Roehrig JT, Hombach J, Barrett AD. Guidelines for Plaque-Reduction Neutralization Testing of Human Antibodies to Dengue Viruses. Viral Immunol. 2008; 21(2): 123-32. doi: 10.1089/vim.2008.0007. PubMed PMID: 18476771 .

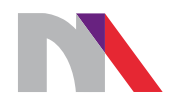

\section{Ministry of Science} and Higher Education

Republic of Poland

Generation of the DOI (Digital Object Identifier) - task financed under the agreement No. 618/P-DUN/2019 by the Minister of Science and Higher Education 